\title{
A new species of Laonice (Spionidae, Polychaeta, Annelida) from Bellingshausen Sea (West Antarctica)
}

\author{
Eduardo López
}

Received: 2 November 2009 / Revised: 30 December 2010 / Accepted: 20 January 2011 / Published online: 12 February 2011

(c) Springer-Verlag and AWI 2011

\begin{abstract}
During the Antarctic summers of 2002-2003 and of 2005-2006, the Spanish BENTART cruises were conducted to the Bellingshausen Sea (Western Antarctica), aiming to study its benthic communities, from depths ranging from 100 to $2,000 \mathrm{~m}$. To achieve it, 30 stations were selected; each one was surveyed in such a way that the infaunal, epifaunal and suprabenthic components of the communities were sufficiently characterized. As a part of the study, some spionid individuals were identified as belonging to a new species of the genus Laonice Malmgren, 1867. The new species belongs to a group within the genus that is characterized by the presence of more than two rows of very numerous capillary chaetae in both noto- and neuropodial fascicles of anterior part of the body. However, it can be readily distinguished from the rest of species within the group by the posterior position in which neuropodial pouches appear (chaetiger 16 or 17) and by the caruncle reaching posteriorly chaetiger 19 . In addition, other remarkable features of the new species are the short and triangular occipital tentacle, the rudimentary eyes, the hooded neuropodial hooks first appearing in chaetigers 34-37 and the sabre neurochaetae first occurring in chaetigers $20-27$.
\end{abstract}

Keywords Antarctica $\cdot$ Polychaetes $\cdot$ Spionidae . Benthic species $\cdot$ New species

Communicated by Peter Funch.

\section{E. López $(\bowtie)$}

Facultad de Ciencias, Departamento de Biología (Zoología), Laboratorio de Biología Marina,

Universidad Autónoma de Madrid,

Cantoblanco, 28049 Madrid, Spain

e-mail: eduardo.lopez@uam.es

\section{Introduction}

Spionidae is one of the most diverse polychaete families, and they can be easily recognized by the presence of a pair of long and grooved ciliated palps, although these structures are easily lost when preserved. Other characteristic traits of the family are the presence of hooded hooks in a variable number of chaetigers (usually combined with bilimbated capillaries in the same or different chaetigers), the postchaetal lamellae associated with both noto- and neuropodia in anterior segments and the branchiae lying dorsally and more or less separated from notopodial postchaetal lamella. Members of this family are dominant in soft bottoms from intertidal to abyssal depths inhabiting in tubes constructed of sediment and mucus, whereas some species can bore mollusc shells having economic impact as plagues in shellfish farms and fisheries (Rouse and Pleijel 2001). Adult spionids use their palps either to collect food from the water column or to selectively collect particles from sediment surface, and several species are capable of changing their feeding strategy depending on the presence of food in the sediment or the water (Blake 1996).

During the Antarctic summers of 2002-2003 and of 20052006, the Spanish cruises BENTART to the Bellingshausen Sea were conducted on board R/V Hesperides. The studied area extended from the Antarctic Peninsula $\left(70^{\circ} \mathrm{W}\right)$ to the Thurston Island $\left(100^{\circ} \mathrm{W}\right)$, with a northern limit defined by the bathymetric line of 2,000 $\mathrm{m}$ and a southern one by the border of permanent ice cover (Ramos and Moya 2003). In the study, numerous individuals of various spionid species were identified. Most of them pertained to well-known Antarctic species, but some specimens belonged to a new species of the genus Laonice Malmgren, 1867; in the present paper, a taxonomic account of this taxon is given. Although the genus has never been defined in terms of phylogenetic relationships, it 
appears to be an unambiguous monophyletic group composed of about 24 described species (Radashevsky and Lana 2009), and characterised by their anteriorly rounded prostomium, the absence of hooks in the notopodia and the branchiae separated from the notopodial lamellae and occurring from chaetiger 2 in adults. In addition, most species within the genus have an occipital tentacle and neuropodial pouches. Since most species diagnoses rely on combination of morphometric characteristics, many misidentifications occurred in the past resulting in dubious geographical ranges for supposedly cosmopolitan species. However, recent regional revisions (Sikorski 2003; Aguirrezabalaga and Ceberio 2005; Radashevsky and Lana 2009) are clarifying this problem, a trend that can be expected to continue with further research.

\section{Materials and methods}

Since the goal of the project was to get a complete picture of the benthic community at each station, at every site a number of sampling devices were employed. Epibenthic samples were taken using an Agassiz trawl with $2 \mathrm{~m}$ wide and $1.12 \mathrm{~m}$ high mouth, and with a $10 \mathrm{~mm}$ gauge mesh in the collecting bag. The gear was towed over the sea bottom for 5-10 min at 1.5-2 knots in every station. However, in many sites it was impossible to obtain quantitative samples because the sediment was sticky enough to clog the bag before the run was completed. The suprabenthic fauna was collected by means of a sledge equipped with three superimposed nets $(0.5 \mathrm{~mm}$ gauge) that simultaneously sampled the fauna in the 10-50, 55-95 and 100-140 cm near-bottom water layers; this device was towed for 2-12 min at 1.5-2 knots. Finally, a box-corer grab with $50 \times 50 \mathrm{~cm}$ square-section corers was used for endofaunal samples. Since the device was powerful enough, in every site the corers were introduced in the sediment down to $60 \mathrm{~cm}$ depth and the collected sediment volume was always the same, so the endofaunal samples were quantitatively comparable. Further details on the sampling procedures can be found in Ramos and Moya (2003), Saiz et al. (2008) and San Vicente et al. (2009).

Irrespective of the sampling gear operated, the sediment collected was processed in the same way. Fine particles were washed away through a column of sieves with a minimum gauge mesh of $1 \mathrm{~mm}$. The retained material was sorted using stereomicroscopes in the ship; polychaetes were identified to family level and fixed in $4 \%$ formalin in sea water. Specimens pertaining to family Spionidae were examined using a stereomicroscope and a compound microscope with differential contrast optics (Nomarski) provided of a drawing tube for the figures. Body width measurements exclude parapodia, branchiae or cirri. Two specimens were dehydrated and gold coated for SEM study following standard procedure, after which they resulted badly deteriorated; the remainder of the specimens were preserved in $70 \%$ ethanol and deposited in Museo Nacional de Ciencias Naturales de Madrid (MNCNM).

\section{Results}

Systematic account

Family Spionidae Sars, 1872.

Genus Laonice Malmgren, 1867.

Laonice vieitezi sp. n. (Figs. 1, 2).

Examined material

Holotype: MNCN 16.01/11614, 6949'33.6"S-7743'40.8' W, Agassiz trawl, mud, 605 m (13 February 2003). Paratypes:

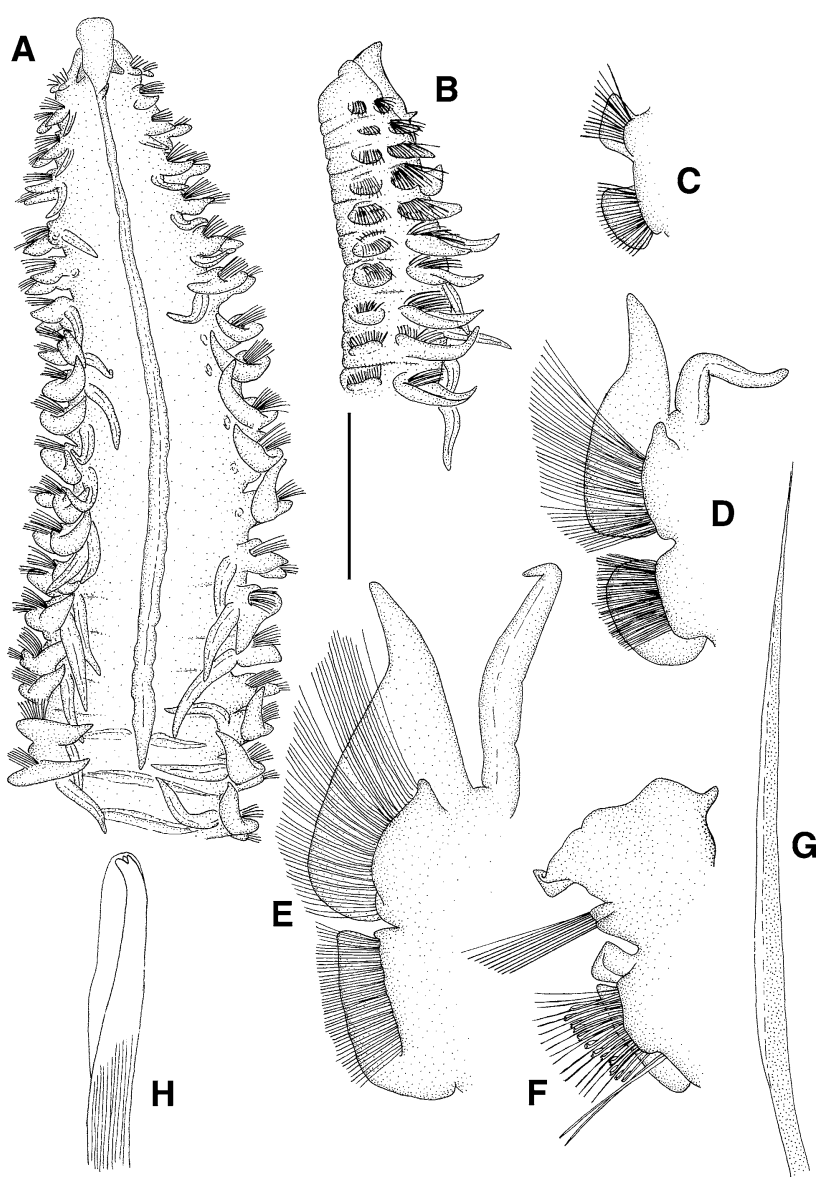

Fig. 1 Laonice vieitezi $\mathrm{sp.} \mathrm{n}$. a Anterior end, dorsal view, holotype; b Anterior end, lateral view, holotype. c Chaetiger 1, parapodium in anterior view, paratype MNCN 16.01/11618. d Chaetiger 5, parapodium in anterior view, paratype MNCN 16.01/11618. e Chaetiger 13, parapodium in anterior view, paratype MNCN 16.01/11618. f Chaetiger 50, parapodium in anterior view, holotype. g Chaetiger 5, capillary notochaeta, paratype MNCN 16.01/11618. h Chaetiger 50, neuropodial hooded hook, holotype. Scale bar a-b $2.8 \mathrm{~mm}, \mathbf{c}-\mathbf{f} 1 \mathrm{~mm}$, g $96 \mu \mathrm{m}, \mathbf{h} 48 \mu \mathrm{m}$ 

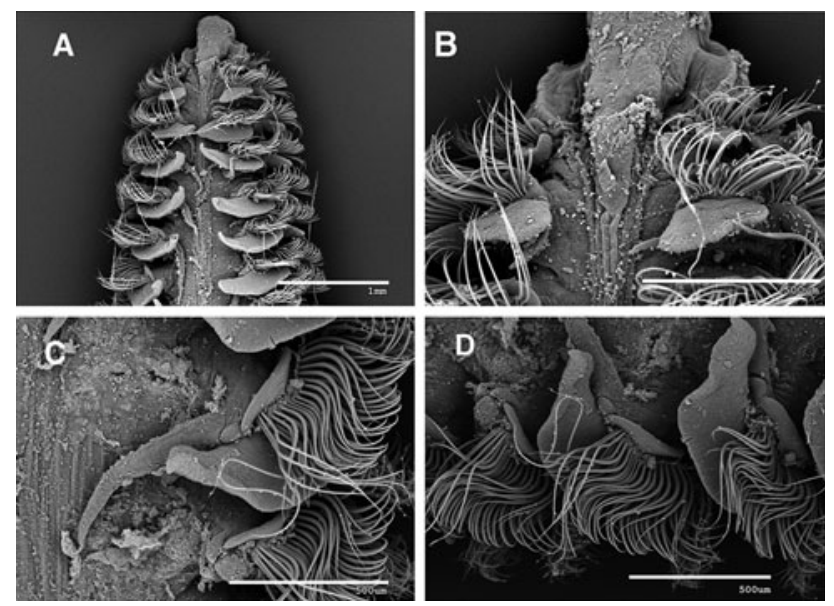

Fig. 2 Laonice vieitezi sp. n. a Anterior end, dorsal view, additional material. b Detail of the same specimen showing the occipital tentacle. c Chaetiger 13 of the same specimen, right parapodium in dorsal view, showing branchia, notopodial prechaetal lobe and notopodial postchaetal lamella. d Chaetigers 12-14 of the same specimen, right side in dorso-lateral view, showing branchiae, notopodial prechaetal lobes and notopodial postchaetal lamellae. Scale bars a $1 \mathrm{~mm}, \mathbf{b}-\mathbf{d} 0.5 \mathrm{~mm}$

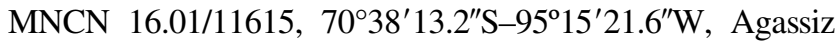
trawl, sandy mud with gravel, $534 \mathrm{~m}$ (30 January 2003), one paratype. MNCN 16.01/11616, 70 $38^{\prime} 13.2^{\prime \prime} \mathrm{S}-95^{\circ} 15^{\prime} 21.6^{\prime \prime} \mathrm{W}$, box-corer dredge, sandy mud with gravel, $534 \mathrm{~m}$ (30 January 2003), one paratype. MNCN 16.01/11617, $70^{\circ} 44^{\prime} 18.6^{\prime \prime} \mathrm{S}-$ $81^{\circ} 27^{\prime} 51^{\prime \prime} \mathrm{W}$, box-corer dredge, sandy mud with gravel, $497 \mathrm{~m}$ (11 February 2003), one paratype. MNCN 16.01/11618, $69^{\circ} 49^{\prime} 33.6^{\prime \prime} \mathrm{S}-77^{\circ} 43^{\prime} 40.8^{\prime \prime} \mathrm{W}$, Agassiz trawl, sandy mud, $605 \mathrm{~m}$ (13 February 2003), one paratype. MNCN 16.01/ $11619,69^{\circ} 58^{\prime} 50.4^{\prime \prime} \mathrm{S}-87^{\circ} 29^{\prime} 2.4^{\prime \prime} \mathrm{W}$, suprabenthic sledge, mud, $1801 \mathrm{~m}$ (26 January 2006), one paratype. MNCN 16.01/ 11620 , $69^{\circ} 56^{\prime} 58.8^{\prime \prime} \mathrm{S}-86^{\circ} 19^{\prime} 16.2^{\prime \prime} \mathrm{W}$, suprabenthic sledge, sandy mud, $1426 \mathrm{~m}$ (27 January 2006), two paratypes. Two specimens dehydrated for SEM, $70^{\circ} 38^{\prime} 13.2^{\prime \prime} \mathrm{S}-95^{\circ} 15^{\prime} 21.6^{\prime \prime} \mathrm{W}$, box-corer dredge, sandy mud with gravel, $534 \mathrm{~m}$ (30 January 2003).

\section{Description of the type material}

Holotype is the largest specimen; incomplete, an anterior fragment $37 \mathrm{~mm}$ long, $4 \mathrm{~mm}$ wide for 42 chaetigers, plus two median fragments of nine and 13 chaetigers, respectively; posterior end lacking. Anterior part of body flattened, with intersegmental furrows indistinct on dorsal surface; colour in alcohol light brown to yellow. Prostomium (Figs. 1a, 2a) bell shaped, broad anteriorly, sometimes very weakly incised; not fused with peristomium; eyes absent or present as only one pair of minute, deeply imbedded ones consisting each in 2-3 pigmented cells; occipital tentacle (Figs. 1a-b, 2b) rudimentary, triangular; caruncle (Fig. 1a) long, continuing posteriorly to chaetigers 16-19. Peristomial lateral wings not rising above prostomium
(Fig. 1b), their length little more than half of that of prostomium. Palps not observed. Chaetiger 1 slightly shorter than chaetiger 2 (Fig. 1a-b), with triangular, short notopodial postchaetal lamellae and rounded neuropodial lamellae (Figs. 1c, 2b); postchaetal lamellae of following chaetigers increasingly larger, triangular and acutely pointed in notopodia, cordiform in neuropodia (Figs. 1d-e, 2c-d); lamellae of median and posterior chaetigers very thin, membranous, rounded and backward directed in notopodia, neuropodial lamellae rectangular, from chaetiger 50 sometimes showing an incision above the neurochaetae (Fig. 1f). Prechaetal lamellae present in noto- and neuropodia from chaetiger 1; first rounded, then as low ridges in anterior chaetigers, notopodial one slightly longer and dorsally pointed (Figs. 1c-e, 2b-d); in median and posterior chaetigers much shorter, inconspicuous in notopodia, rounded in neuropodia (Fig. 1f). Capillaries with narrow sheath (unilimbate), with fine granules imbedded in shaft (Fig. 1g); first parapodia with about 15 straight capillaries in notopodium and 24 in neuropodium, arranged in two rows in each bundle (Fig. 2b); following chaetigers with noto- and neuropodial fascicles bearing curved, larger and more numerous capillary chaetae arranged in 4-5 rows, at first bearing about 70 notochaetae and 60 neurochaetae, then increasing progressively to about 100 notochaetae and 90 neurochaetae (Fig. 2d). Neuropodial hooded hooks present from chaetigers 34-37; hooks (Fig. 1h) tridentate with main fang surmounted by a pair of smaller apical teeth arranged side by side; shaft stout and finely striated, without inner granules; accompanied by about 17 slender, straight, nongranulated capillaries and by one to three long and stouter sabre chaetae from chaetigers $20-27$; corresponding notopodia bearing about 20 capillaries similar to those of anterior chaetigers, but thinner and not so curved; notopodial hooks absent. Branchiae from chaetiger 2; small, cirriform at first (Figs. 1a, d, 2a-b), increasing in length and thickness over following 15 or so segments (Figs. 1a, e, 2c); separated from notopodial postchaetal lamella; exact number of branchiae impossible to define, since all the specimens are incomplete, but extending at least to chaetiger 42. Dorsal crests on posterior half of each segment from chaetiger 18, low and entire (Fig. 1a); from chaetigers 18 to 35 two crests in each segment, crests single thereafter. Neuropodial pouches first present in chaetigers 16 or 17, occurring in every segment thereafter. Pygidium absent in all specimens studied.

\section{Etymology}

The new species is named in honour of Prof. Dr. José Manuel Viéitez, of Universidad de Alcalá de Henares, in appreciation of his important contributions to the knowledge of the ecology and systematics of Spionidae, besides his friendly teaching in the beginning of the author's career. 
Table 1 Taxonomic characters of the Antarctic species of Laonice (Hartman 1953, 1978; Blake 1983; Radashevsky and Lana 2009)

\begin{tabular}{|c|c|c|c|}
\hline & L. antarcticae & L. weddellia & L. vieitezi $\mathrm{n}$. sp. \\
\hline Frontal horns & Present & Absent & Absent \\
\hline Occipital tentacle & Long, digitiform & Short, digitiform & Short, triangular \\
\hline Eyes & Rudimentary or absent & Distinct & Rudimentary or absent \\
\hline Maximum length of caruncle & To chaetiger 12 & To chaetigers $12-20$ & To chaetigers $16-19$ \\
\hline $\begin{array}{l}\text { Rows of capillaries in } \\
\text { anterior podial lobes }\end{array}$ & Up to two & Up to five & Up to five \\
\hline Start of sabre chaetae & Chaetigers 23-24 & Chaetigers $11-13$ & Chaetigers 20-27 \\
\hline Start of neuropodial hooks & Chaetigers $35-40$ & Chaetigers 20-21 & Chaetigers $34-37$ \\
\hline Start of neuropodial pouches & Chaetigers $4-5$ & Chaetigers 8-11 & Chaetigers $16-17$ \\
\hline
\end{tabular}

\section{Remarks}

Laonice vieitezi sp. nov. belongs to a group of species within the genus characterized by numerous capillaries arranged in more than two rows in anterior parapodia (Aguirrezabalaga and Ceberio 2005); this group also encompasses L. appelloefi Soderstrom, 1920, described from Norway, L. weddellia Hartman, 1978, from Antarctica, L. blakei Sikorski, Jirkov and Tsetlin, 1988, from Arctic, L. nuchala Blake, 1996, from California, L. norgensis Sikorski, 2003, from Norway, and L. maciolekae Aguirrezabalaga and Ceberio, 2005, from the Bay of Biscay. Laonice vietezi differs from these species by more posterior start of neuropodial pouches. Thus, in $L$. appelloefi, they first appear in chaetiger 7 (Sikorski 2003), in L. blakei in chaetiger 3 (Sikorski 2003), in L. nuchala in chaetigers 7 or 8 (Blake 1996) and in L. macioleckae in chaetigers 6 or 7 (Aguirrezabalaga and Ceberio 2005). These four species also can be distinguished by the more anterior occurrence of sabre chaetae, which ranges from chaetiger 10 to chaetiger 13 (for L. nuchala this information is lacking in the original description), their shorter caruncles, which never extend further than chaetiger 14, and by their occipital tentacle, which are digitiform instead of rudimentary, except for $L$. appelloefi that also bears a poorly developed one. A more similar species is L. norgensis (Sikorski 2003). In this species, important characters such as caruncle length and first occurrence of neuropodial pouches show noticeable intraspecific variation, so the states present in L. vieitezi might fit within the range. However, the new species herein described presents rudimentary instead of distinct eyes, short and triangular instead of digitiform occipital tentacle, four or five rows of capillaries instead of three, sabre chaetae starting in chaetigers 20-27 instead of 10-18 and neuropodial hooded hooks first appearing in chaetigers 34-37 instead of 16-31. The two other Laonice species previously recorded in Antarctic waters have been also collected during the BENTART cruises: the aforementioned L. weddellia and L. antarcticae Hartman, 1953. Their characteristics are summarized in
Table 1 together with those of $L$. vietezi. Laonice weddellia is similar to $L$. vieitezi in having capillaries arranged in up to five rows in anterior parapodial lobes, rounded prostomium with a short occipital tentacle and similarly long caruncle, which can extends backwards to chaetigers 12-20. However, in this species neuropodial pouches start in a more anterior segment (chaetigers 8 to 11 ), as well as the hooks that appear in chaetigers 20 or 21 (Hartman 1978; Blake 1983), and the sabre chaetae that appear in chaetigers 11-13 (Radashesky and Lana 2009). On the contrary, the second one do not belong to the same group of species, since it only bears two rows of capillaries in the fascicles of the anterior part of the body (Hartman 1953; Blake 1983). In addition it has a prostomium with frontal horns, caruncle that extends up to chaetiger 12, neuropodial pouches from chaetigers 4-5. In this species, neuropodial hooded hooks start in chaetigers 35-40 and sabre chaetae in chaetigers 23-24 (Radashesky and Lana 2009), fitting within the range of L. vieitezi.

Acknowledgments The present study was financially supported by the Spanish Ministerio de Ciencia y Tecnología through the research projects "Estudio integrado de la biodiversidad bentónica del Mar de Bellinghausen y península Antártica (Antártida del Oeste). Primera campaña de muestreo a bordo del B/O Hespérides. REN2001-1074/ ANT" and "Estudio integrado de la biodiversidad bentónica del mar de Bellingshausen y península Antártica. Segunda campaña de muestreo a bordo del B/O Hespérides. CGL2004/01856". The author wishes to express his gratitude to the crew of $\mathrm{B} / \mathrm{O}$ Hesperides as well as to the research staff of the project, especially to Dr. Ana Ramos and Dr. Julio Parapar, for their collaboration both aboard the ship and on land. Javier Sánchez, Francisco Yagüe and Patricia Álvarez from Museo Nacional de Ciencias Naturales in Madrid are gratefully obliged for the loan and management of the studied material. The very valuable comments of two anonymous referees, which greatly improved the quality of the present work, are sincerely acknowledged.

\section{References}

Aguirrezabalaga F, Ceberio A (2005) Spionidae (Annelida: Polychaeta) from the Capbreton Canyon (Bay of Biscay, NE Atlantic) with description of a new genus and three new species. Mar Biol Res 1:267-280 
Blake JA (1983) Polychaetes of the family Spionidae from South America, Antarctica, and adjacent seas and islands. Biology of the Antarctic Seas, XIV. Antarctic Res Ser 39(3):205-288

Blake JA (1996) Family Spionidae Grube, 1850. Including a review of the genera and species from California and a revision of the genus Polydora Bosc, 1802. In: Blake JA, Hilbig B, Scott PH (eds) Taxonomic atlas of the benthic fauna of the Santa Maria Basin and Western Santa Barbara Channel, vol 6. The Annelida. Part 3. Polychaeta: Orbiniidae to Cossuridae. Santa Barbara Museum of Natural History, Santa Barbara, pp 81-223

Hartman O (1953) Non-pelagic polychaeta of the Swedish Antarctic Expedition 1901-1903. Furth Zool Results Swed Antarctic Exped $4(11): 1-83$

Hartman O (1978) Polychaeta from the Weddell Sea Quadrant, Antarctica. Biology of the Antarctic Seas, VI. Antarctic Res Ser 26(4):125-223

Radashevsky VI, Lana PC (2009) Laonice (Annelida: Spionidae) from South and Central America. Zoosymposia 2:265-295
Ramos A, Moya F (2003) Estudio integrado de la biodiversidad del bentos del mar de Bellingshausen y península Antártica (Antártica del Oeste). Informe de resultados de la campaña Bentart-2003. Instituto Español de Oceanografía, Málaga

Rouse GW, Pleijel F (2001) Polychaeta. Oxford University Press, Oxford

Saiz JI, García FJ, Manjón ME, Parapar J, Peña-Cantero A, Saucède T, Troncoso JS, Ramos A (2008) Community structure and spatial distribution of benthic fauna in the Bellingshausen Sea (West Antarctica). Pol Biol 31:735-743

San Vicente C, Munilla T, Corbera J, Sorbe J-C, Ramos A (2009) Suprabenthic fauna from the Bellingshausen Sea and western Antarctic Peninsula: spatial distribution and community structure. Sci Mar 73:357-368

Sikorski AV (2003) Laonice (Polychaeta, Spionidae) in the Arctic and the North Atlantic. Sarsia 88:316-345 